Bulletin UASMV serie Agriculture 70(1)/2013, 397-402

Print ISSN 1843-5246; Electronic ISSN 1843-5386

\title{
Quantitative Assessment Method of Illegal Dumping in Small Rivers Case Study: Neamț County, Romania
}

\section{Florin -Constantin MIHAI*}

Faculty of Geography and Geology „Alexandru Ioan Cuza” University, Carol I Avenue No.20A, RO-700505, Iaşi, Romania; mihai.florin86@yahoo.com

\begin{abstract}
Poor waste management facilities from Romanian rural areas lead to uncontrolled waste disposal on improper sites. These bad practices are frequently in the the proximity of built-up areas, therefore, the small rivers inside these areas are susceptible to waste dumping. The paper aims to develop a quantitative assessment method of waste disposed into such small rivers from extraCarpathian region of Neam $\square$ county. The lack of organized waste collection services from 2003 lead to high values of waste disposed in such rivers frequently over $15 \mathrm{t} / \mathrm{yr}$ for each one. Despite some improvements compared to 2003 the small rivers inside built-up areas of villages are still highly exposed to waste dumping. The values vary depending on demographic and geographic features of each locality and on the other side, due to the presence of an organized waste collection system. The results and comparative analysis between 2003 and 2010 show some positive changes but the illegal dumping issue is far from being eliminated.
\end{abstract}

Keywords: assessment method, illegal dumping, rivers, waste management, rural areas

\section{INTRODUCTION}

Illegal dumping is most common environmental threat related to waste management issue across the world (Chen, 2010; Ichinose and Yamamoto, 2011, Karak et al., 2012 ; Rotich et al., 2006).

Also, EU acquis fights against the bad practices encountered across member countries but major disparities are outlined concerning the performance of national or regional waste management systems (Manzzati and Zoboli, 2008; Mihai and Apostol, 2012a). Rural areas from Romania are susceptible to illegal dumping due to the poor waste collection services (Apostol and Mihai, 2012; Mihai, 2012a). Development of waste management infrastructure is emerging in last years at regional and local scale (Mihai ș i Apostol, 2012b) but illegal dumping remains a major environmental threat.

Quantitative assessment methods of illegal dumping are performed in recent years for various geographical conditions (Mihai, 2012b, 2013; Mihai et al., 2012a, 2013).

These methods are based on specific indicators calculated at commune or village level. Spatial analysis of rural dumpsites parameters (surfaces, volumes) also reflects certain patterns in their distribution (Mihai et al., 2012b; Mihai and Lămăș anu, 2013).

Geography of waste studies these interactions between natural, demographic and socio-economic features and their implication to a certain territory (Bertrand and Laurent, 2003; Le Dorlot, 2004; Davies, 2008; Mihai, 2012c).

Rivers in the proximity of human settlements are the most vulnerable environmental factors to such bad practices. 


\section{MATERIALS AND METHODS}

The small rivers located in Subcarpathian and plateau regions of the county are susceptible to uncontrolled waste disposal, this bad practice were also confirmed by field observations in 2009-2011. This method aims to quantify the amounts (estimates) of waste uncontrolled disposed in small rivers that cross the built-up areas of villages .

It is based on the same proximity and convenience principle as others quantitative methods applied at commune level for administrative territorial units (Mihai, 2012b) or for mountain rivers at village scale (Mihai et al., 2012a), but it is more difficult to apply because the built-up area of a village is often crossed by several rivers, and the creeks in the proximity or within villages are an alternative option along with other waste disposal sites (loam sites, pastures, degraded lands, local roadsides). Therefore, the gap distance between the outer limit of the built-up area and the creek (small river) is less between 0.001 to $0.6 \mathrm{~km}$.

Also, villages taken into consideration must not be crossed by several small rivers because the estimation per creek can not be achieved. Values of $\mathrm{Q}_{\mathrm{ud}}$ indicator (amounts of waste uncontrolled disposed) calculated for 2003 and 2010 provide a quantitative approach of illegal dumping impact related to the average distance between the outer limit of the builtup area and the creek in question according to the table 1:

Tab.1

Correlation between $\mathrm{Q}_{\mathrm{ud}}$ and average distance $\left(\mathrm{A}_{\mathrm{d}}\right)$

\begin{tabular}{|c|c|}
\hline $\begin{array}{c}\text { Average distance between creek \& outer } \\
\text { limit of built-up area (village) }\end{array}$ & The share of $\mathrm{Q}_{\mathrm{ud}}$ \\
\hline $600-400(\mathrm{~m})$ & 0.2 \\
\hline $399-300$ & 0.4 \\
\hline $299-200$ & 0.6 \\
\hline $199-100$ & 0.8 \\
\hline $99-1$ & 0.9 \\
\hline
\end{tabular}

Thus, the amounts of waste disposed in small rivers/creeks $\left(\mathrm{Q}_{\mathrm{wsr}}\right)$ is calculated as follows: $\mathbf{Q}_{\mathbf{w s r}}(\mathbf{t} / \mathbf{y r})=\mathbf{Q}_{\mathbf{u d}} * \mathbf{S}_{\mathbf{A d}}$, Sad - share of $\mathbf{Q}_{u d}$ indicator according to $\mathrm{A}_{\mathrm{d}}$

The average distance is calculated at least in 5 reference points for small villages and 10 reference points in case of stretched villages along the valleys (eg Urecheni, Rădeni) or $5 / 5$ points for both sides of the streams that cross through built-up areas. These distances are measured using GoogleEarth satellite images (an easy and accessible tool), further is performed an arithmetic mean of these benchmarks as shown in fig.1

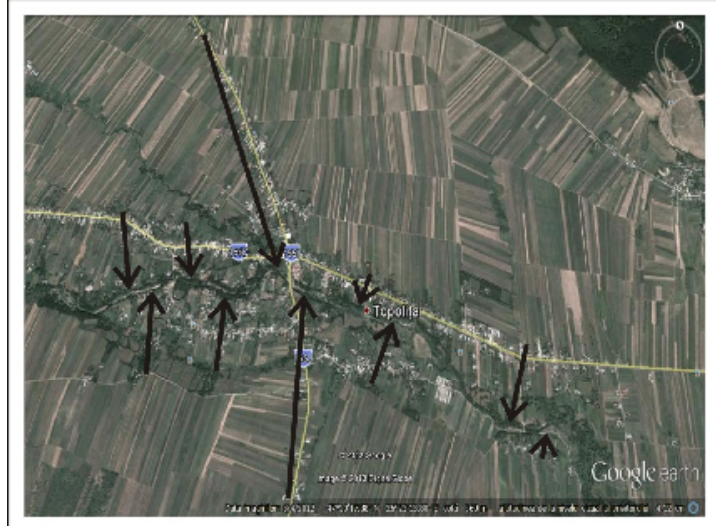

Topolița village - homonymous creek

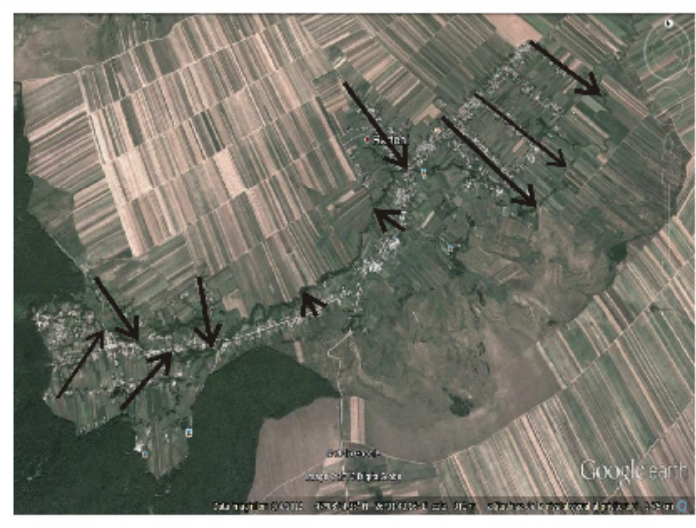

Rădeni village - Rădeanca creek

Fig. 1. Reference points for calculation of average distance ( Ad) 
Most vulnerable creek is that which has a course through the middle of built-up area of a well populated village, without access to waste collection services or a low collection efficiency. This method can estimate the impact of a settlement (concerning the waste dumping) on a creek in the proximity only in certain local geographical conditions.

In this context, for the most accurate estimation is taken into consideration only those water courses that meet the following conditions:

$>$ are located in extra-Carpathian region of county,

$>$ the creeks longitudinally cross the built-up areas of localities

$>$ these built-up areas must not be crossed by several water courses (except for small tributaries within the built-up areas)

$>$ average distance of the last households (outer limit of the built-up area) from the creek must not exceed $600 \mathrm{~m}$.

The assessment is performed for 2003 (pre-accession period) and 2010 (postaccession ) according to the past and current waste management facilities from study area.

\section{RESULTS AND DISCUSSIONS}

Tentacular morphology of built-up areas along the streams does not allow an adequate measurement of reference points in order to fit the whole village in a certain class of $\mathrm{Q}_{\mathrm{ud}}$ indicator (according to $\mathrm{A}_{\mathrm{d}}$ ) especially for villages from Subcarpathian region such as Agapia, Ghindăoani, Grumăzeşti, Bal ăte ti, Răucesti \& Petricani communes or for those located in Moldavian Plateau (eg. Stani a, Ion Creangă etc).

Demographic factors (population of the village), the access to sanitation services, the morphology of the village, the average distance between the outer limit of the built-up area and the stream have direct implications for values of $\mathrm{Q}_{\mathrm{wsr}}$ indicator.

This paper includes the impact assessment of 18 villages in the vicinity of small rivers, it is noted that the most vulnerable in terms of estimated amounts (in 2003) were the following creeks: Râiosu (73t/yr), $\square$ olici (56,4 t/yr), Poiana, Târzia, Rădeanca, Ruginoasa, Sârbilor (> 30 t/yr), Bozieni, Obârș ia, Valea Morilor Valea Neagră ( $>20$ t/yr). On the other side, values above $20 \mathrm{t} / \mathrm{yr}$ of $\mathrm{Q}_{\mathrm{wsr}}$ were recorded in 2010 for Râiosu (30.8 t / yr), Rădeanca (41.2 t / yr), Tolici and Valea Neagră (> 20 t / yr) creeks.

In addition to access of waste collection services which decreases the value of $\mathrm{Q}_{\mathrm{ud}}$ indicator, lower values of $\mathrm{Q}_{\mathrm{wse}}$ is also due to the average distance $>400 \mathrm{~m}$ between the outer limit of built-up area and the creek course analyzed as for settlements Agapia, Topoli $\square$ a, Negreș ti or one the other side, associated with a low population such as for Rocna village for Glodeni creek. Also, the small villages reflect the the low values of $\mathrm{Q}_{\mathrm{wsr}}$ indicator even if the share of average distance is 0.8 (eg. Târzia village).

Comparative analysis $\mathrm{Q}_{\mathrm{wsr}}$ indicator between 2003 (when waste collection services were absent in most rural areas) and 2010 (when improper dumpsites were closed and more or less proper waste managemnet services have been implemented) reflects improvements in reduction of illegal dumping impact on small rivers, the difference between $482.32 \mathrm{t} /$ $287.54 \mathrm{t}$ is significant.

However, field observations in 2009-2011 revealed that this bad practice is still present across localities with access to such services such as Târpeşti, Petricani \& Ingăreşti villages (waste dumped into Topolita creek), Agapia village (Agapia creek), Oglinzi village (Sărata creek). 
Values of $\mathrm{Q}_{\mathrm{wsr}}$ indicator for 2003 and 2010

\begin{tabular}{|l|l|r|r|r|r|r|r|}
\hline Village & Creek (stream) & \multicolumn{1}{|l|}{$\mathbf{A}_{\mathbf{d}}$} & $\mathbf{S}_{\text {Ad }}$ & $\mathbf{Q}_{\text {ud }} \mathbf{2 0 0 3}$ & $\mathbf{Q}_{\text {wsm }} \mathbf{2 0 0 3}$ & $\mathbf{Q}_{\text {ud }} \mathbf{2 0 1 0}$ & Qwsr2010 \\
\hline Urecheni & Râiosu & 0,39 & 0,4 & 182,785 & 73,114 & 77,04 & 30,816 \\
\hline Rădeni & Rădeanca & 0,38 & 0,4 & 97,83 & 39,132 & 103,09 & 41,236 \\
\hline Valea Alba & Valea Albă & 0,304 & 0,4 & 26,85 & 10,74 & 11,31 & 4,524 \\
\hline Târzia & Târzia & 0,302 & 0,4 & 44,31 & 17,724 & 18,679 & 7,4716 \\
\hline Poiana & Culeș $a$ & 0,338 & 0,4 & 49,54 & 19,816 & 20,88 & 8,352 \\
\hline Agapia & Agapia & 0,407 & 0,2 & 79,09 & 15,818 & 47,62 & 9,524 \\
\hline Netezi & Netezi & 0,182 & 0,8 & 13,6 & 10,88 & 5,733 & 4,5864 \\
\hline Tolici & $\square$ olici & 0,206 & 0,6 & 94 & 56,4 & 39,66 & 23,796 \\
\hline Topoli $\square$ a & Topoli $\square a$ & 0,416 & 0,2 & 98,135 & 19,627 & 41,36 & 8,272 \\
\hline Negreș ti & Horai $\square a$ & 0,594 & 0,2 & 92,491 & 18,4982 & 97,464 & 19,4928 \\
\hline Ruginoasa & Ruginoasa & 0,327 & 0,4 & 99,679 & 39,8716 & 42,01 & 16,804 \\
\hline Dulceș ti & Valea Neagră & 0,344 & 0,4 & 65,284 & 26,1136 & 68,79 & 27,516 \\
\hline Iucș a & Bozieni & 0,216 & 0,6 & 40,513 & 24,3078 & 42,6 & 25,56 \\
\hline Lunca & Poiana Lungă & 0,181 & 0,8 & 20,13 & 16,104 & 21,22 & 16,976 \\
\hline Butnăreș ti & Valea Morilor & 0,284 & 0,6 & 49,12 & 29,472 & 20,7 & 12,42 \\
\hline Bârjoveni & Obârș ia & 0,285 & 0,6 & 40,63 & 24,378 & 17,126 & 10,2756 \\
\hline Secuieni & Sârbilor & 0,298 & 0,6 & 58,6 & 35,16 & 24,13 & 14,478 \\
\hline Rocna & Glodeni & 0,576 & 0,2 & 25,84 & 5,168 & 27,23 & 5,446 \\
\hline Total & & & & 1178,427 & 482,3242 & 726,642 & 287,5464 \\
\hline
\end{tabular}

Villages without waste collection services (in 2003-2010) continued to dispose the waste generated on creeks such as Horai $\square$ a (Negreș ti \& Dobreni villages ), Almaş (Dobreni village ), Iucş a (Bozieni village) etc this fact being confirmed by field observations.

Small rivers which crosses the Subcarpathian hills are mostly vulnerable to waste dumping in the proximity of villages or within built-up areas, this fact being also confirmed for localities which are not included in this case study (eg Mărgineni, Făurei \& Băltăteș ti communes etc). On the other hand, streams (direct tributaries of Bârlad river in the upper sector) which cross Valea Ursului, Oniceni \& Bozieni communes are susceptible to waste disposal, but in a lower proportion, because the open dumps prevailed as as the main option of illegal dumping.

Despite the fact the small rivers are an option often used by local communities for waste dumping, there are some localities which are not susceptible to flooding and waste dumping on surface waters because either their built-up area is not crossed by a creek or it is located at a greater distance from water courses in the vicinity.

This situation is common for settlements developed on the fluvial terraces of major rivers such as: Nisiporeș ti (Boteș ti commune), Hanu Ancu $\square$ ei (Tupila $\square$ i commune), Dumbrava Deal, Izvoare ( Dumbrava Roş ie commune), Plugari (Urecheni commune), Gherăe $\square$ ti Noi, Te $\square$ cani (Gherăeș ti commune), Săbăoani \& Traian (Săbăoani commune).

In these cases, open dumps were the main option in waste disposal, these sites occupied large areas and had higher volumes compared to other settlements in the county ( Mihai et al., 2012, Mihai and Lămaș anu, 2013)

Also, other sites (rather than surface waters) susceptible to uncontrolled disposal of waste is typical for remote settlements, poor exposed to flooding located in the subcarpathian hills and plateau region such as : Cârlig (Dulceș ti commune), Corni, Duş eș ti, Soci, Bordea (Ș tefan cel Mare commune), Unghi (Dragomire $\square$ ti commune), Tu $\square$ canii din Deal (Bahna commune), Baratca (Bârgoani commune), Bogzeș ti (Secuieni commune), Hâr $\square \mathrm{e} \square \mathrm{ti}$ (Mărgineni commune), Băneasa ( Bozieni commune). 
Torrents valleys in the vicinity of the villages are susceptible to waste disposal such as Broşteni, Băhnişoara (Bahna commune), Nistria (Boghicea commune), Avereș ti (Ion Creangă commune) etc. In other localities the streams are often exposed to uncontrolled waste disposal where waste collection services are rudimentary or missing (as shown in fig.2), but performing a quantitative analysis can be achieved only under certain conditions listed above.

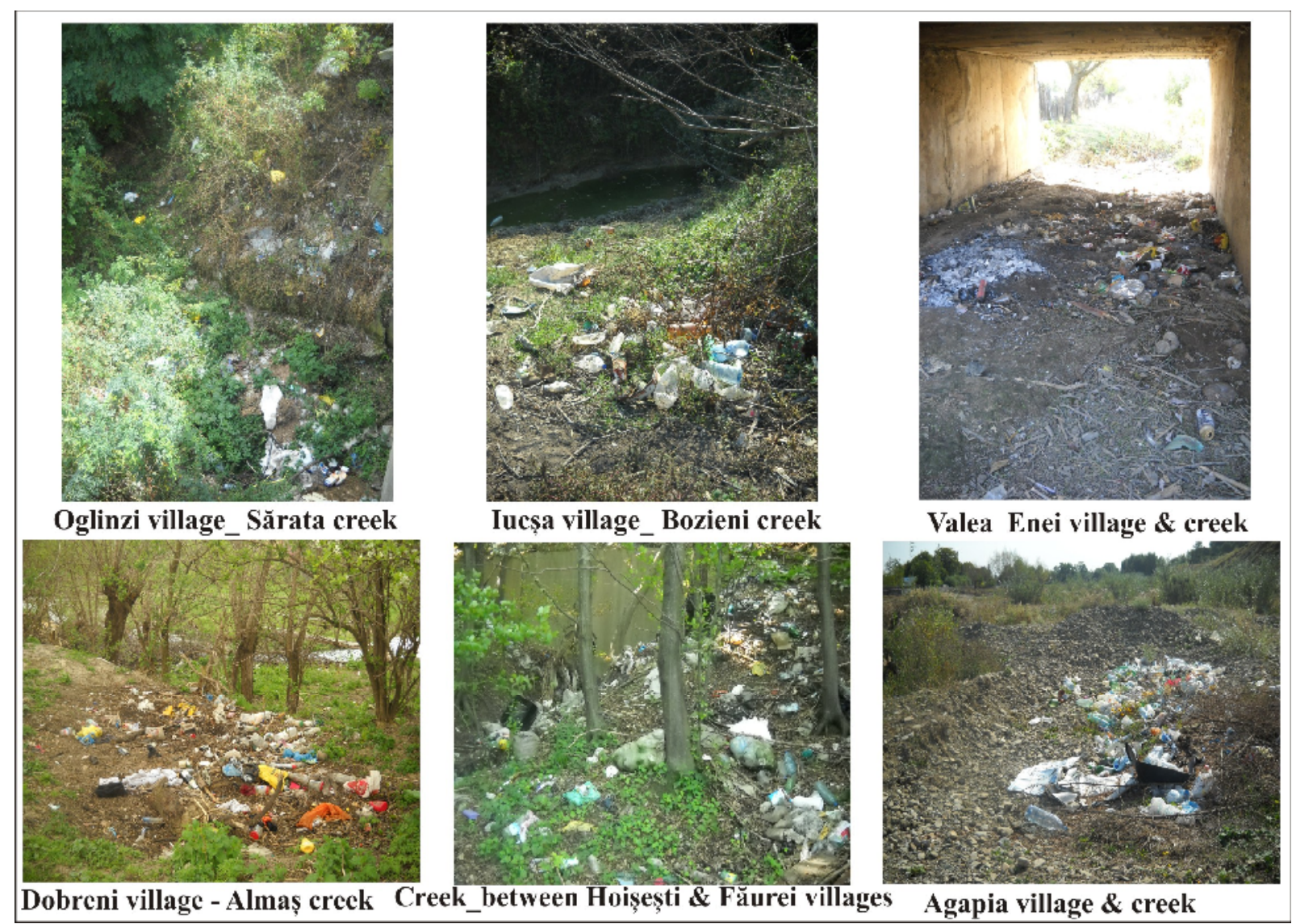

Fig. 1. Waste dumping in small rivers - field observations 2009-2011

\section{CONCLUSION}

The paper propose a method which is intended to evaluate the impact of illegal dumping in small rivers inside the built-up areas of villages from extra-Carpathian region of Neamt County. Determining the estimated amounts of waste disposed into a particular stream by a village can not be calculated unless the geographical conditions permit.

The sites of human settlements are often crossed by several small rivers which at any time may be affected by waste disposal, especially in case of an absent or inefficient waste collection system. Uncontrolled waste disposal is achieved in a dispersed way in villages located on the subcarpathian hills or Moldavian Plateau from Neamt county.

The small rivers are an alternative option for illegal dumping besides the improper dumpsites in the vicinity of households. 


\section{REFERENCES}

1. Apostol, L. and F.C. Mihai. (2012). Rural waste management: challenges and issues in Romania. Present Environment and Sustainable Development. 6 (2):105-114

2. Bertrand, J.R. and F. Laurent (2003). De la décharge à la déchetterie: Questions de géographie des déchets. Rennes, Presses universitaires de Rennes

3. Chen, C.C. (2010). Spatial inequality in municipal solid waste disposal across regions in developing countries. Int. J. Environ. Sci.Tech. 7 (3) :447-456.

4. Davies, A. (2008). The Geographies of Garbage Governance: Interventions, Interactions and Outcomes. Aldershot: Ashgate

5. Ichinose, D. and M. Yamamoto (2011). On the relationship between the provision of waste management service and illegal dumping. Resource and Energy Economics, 33: 79-93

6. Karak, T., R.M. Bhagat and P. Bhattacharyya (2012). Municipal Solid Waste Generation, Composition, and Management: The World Scenario. Critical Reviews in Environmental Science and Technology. 42 (15):1509-1630

7. Le Dorlot, E. (2004). Les déchets ménagers: pour une recherche interdisciplinaire. Strates. 11:1-10

8. Mazzanti, M. and R. Zoboli (2008) Waste generation, waste disposal and policy effectiveness Evidence on decoupling from the European Union, Resources, Conservation and Recycling, 52:1221-1234

9. Mihai, F.C. (2013). Quantitative assessment of household waste disposed in floodplains of rivers from extra-Carpathian region of Neam $\square$ county, Romania. $13^{\text {th }}$ International Multidisciplinary Scientific GeoConference on Ecology, Economics, Education And Legislation, SGEM 2013, Conference Proceedings, vol. 1:781-788

10. Mihai, F.C., A. Ursu, P. Ichim and D.A, Chelaru (2013). Determining rural areas vulnerable to illegal dumping using GIS techniques. Case study: Neam $\square$ County, Romania. $13^{\text {th }}$ International Multidisciplinary Scientific GeoConference on Ecology, Economics, Education And Legislation, SGEM 2013, Conference Proceedings vol.1 : 275-282

11. Mihai, F.C. and A. Lămăș anu (2013). Spatial analysis of dumpsites volumes from rural territory Case study: Neamt County, Romania. Forum Geografic, 12 (1): 59-60

12. Mihai, F.C. (2012). Population access to waste collection services: urban vs rural areas in Romania, Bulletin UASVM Agriculture 69 (2): 464-466

13. Mihai, F.C. (2012). Improper Household Waste Disposal in Rural Territory. Case Study: Neam $\square$ County, Romania. Bulletin USAMV Agriculture 69 (2): 15-20.

14.Mihai, F.C. (2012). Geography of waste as a new approach in waste management study. Lucr. Seminarului Geografic “Dimitrie Cantemir” 33: 39-46

15. Mihai, F.C, L. Apostol, A. Ursu and P. Ichim (2012). Vulnerability of mountain rivers to waste dumping from Neam $\square$ County, Romania. Geographia Napocensis 6 (2):51-59

16. Mihai, F.C., L. Apostol, A.A. Ghiurcă, A. Lămăș anu and A. Bănică, (2012). Geographical distribution of rural dumpsites in North-East Region from Romania, 12 ${ }^{\text {th }}$ International Multidisciplinary Scientific GeoConference SGEM 2012, Conference Proceedings, vol 5 : 447-452, (DOI: $10.5593 /$ sgem2012/s20.v5060)

17. Mihai, F.C. and L. Apostol (2012). Disparities in municipal waste management across EU-27. A geographical approach. Present Environment and Sustainable Development. 6 (1): $169-180$

18. Mihai, F.C. and L. Apostol (2012). Development of waste collection services on rural territory from Neam $\square$ County, Analele Universită $\square$ ii Oradea. Fascicula: Protec $\square$ ia Mediului. 18 (1): 370-375

19. Rotich K.H., Y. Zhao and J. Dong (2006). Municipal solid waste management challenges in developing countries - Kenyan case study. Waste Management 26: 92-100 